\title{
Kerkvereniging en Kerkreg: Geskiedenis, beginsel en praktyk ${ }^{1}$
}

J W Hofmeyr

\section{ABSTRACT}

Church unity and church polity: History, principle and practice

In this article the need for a clearer focus on the history, principles and practice of church polity in the process of church re-unification is addressed. This is specifically focused on the process currently under way in the Dutch Reformed Church family. After an extensive discussion of issues pertaining to the history, principles and practice of church polity within this church family, it is concluded that the process of re-unification need to be implemented with the necessary urgency, but also with patience.

\section{INLEIDING}

Ek het onlangs die besondere ervaring beleef om een van die mees besondere en bekendste natuurbakens ter wêreld te voet te bestyg en wel via die bekende Plattekloofbergpad. Die eindresultaat van hierdie wandelen klimtog was die verruklike Tafelberg met al sy skoonheid en geheimenis. So 'n klimtog is veral vir die ongeoefende geen eenvoudige ervaring nie. Langs die pad beleef 'n mens wisselende momente van frustrasie, moedeloosheid, oorwinning en vergesigte. In die nabyheid en in die verte skiet 'n verskeidenheid van pragtige bakens voor 'n mens op - die Kaap van Storms, van Goeie Hoop, Robbeneiland, die Weskus met al sy prag, die Bolandse berge en die hange oordek met wingerde.

Wanneer 'n mens terugdink aan hierdie ervaring kan 'n mens haas nie anders as om dit in verband te bring met die moeilike en uitdagende proses van kerkvereniging wat tans vir die Ned Geref Kerkfamilie voorlê nie. Juis vir kerke wat in ' $n$ mindere of ' $n$ meerdere mate ongeoefend is as dit by kerkvereniging kom, hou dit sekerlik frustrasie en moedeloosheid in, maar gelukkig ook ervarings van oorwinning en vergesigte. Gelukkig mag ons hoop dat die eindresultaat verruklik sal wees: 'n eindpunt met 'n bepaalde skoonheid en geheimenis met vergesigte wat spreek van goeie hoop en nie van storms nie; bevryding in plaas van bevangenheid; skoonheid in plaas van verdroogtheid; oorwinning en nie van mislukking nie, tekens van vrugbaarheid in plaas van misoeste en vrugteloosheid. 
Tydens so 'n terugdinkproses bring 'n mens onwillekeurig die veelseggende woorde van Benjamin Franklin in herinnering wat by 'n kerkverenigingsproses tersaaklik is: "We must all hang together or assuredly we shall hang separately". Ons bestyg òf saam hierdie uitdaging òf ons gly weg, afsonderlik of gesamentlik in 'n moeras van doelloosheid en mislukking. Mag ons beskeie en uitdagende wekroep wees: "Saam op soek na 'n nuwe weg!".

Die voorveronderstelling waarmee hierdie oorsig aangepak word is dat daar 'n ernstige leemte bestaan om die huidige stand van sake rakende die proses van kerkvereniging in die Ned Geref Kerkfamilie kerkregtelik verantwoord te hanteer, dit wil sê in groter historiese, prinsipiële en praktiese perspektief te plaas. Dis juis in hierdie verband dat hierdie oorsig 'n bydrae wil lewer tot die uitdagende en moeilike gesprek en proses wat ook in 1996 verder gevoer moet word. In sommige kringe word die jaar 1996 as 'n mak- of breekjaar vir hierdie proses beskou². Dit is dus belangrik en tydig om 'n voorraadopname van die huidige situasie te maak.

Heel aan die begin moet ter wille van duidelikheid 'n opmerking oor terminologie gemaak word. Onder kerkeenheid word verstaan dat die kerk van oorsprong een is in God drie-enig. Hierdie eenheid moet te midde van die verskeidenheid in God se skepping onder God se volk en in die verskeurde werklikheid gesoek, gedien en sigbaar gemaak word ${ }^{3}$. Onder kerkvereniging word verstaan die proses van die samevoeging van meer kerkverbande (soos die Ned Geref Kerk, die Verenigende Geref Kerk en die Reformed Church of Africa) tot een kerkverband. Gereformeerde kerkverband is die eenheid van gemeentes in byvoorbeeld ringe en sinodes met een kerkorde op grondslag van Woord en belydenis.

\section{2 'N HISTORIES-KERKREGTELIKE PERSPEKTIEF}

Om 'n duidelike beeld te kry van die huidige kerkregtelike besinning oor die kerkverenigingspoging van die Ned Geref Kerkfamilie, is dit dus van pas en van groot belang om die histories-kerkregtelike verloop van sake kortliks in fokus te bring.

Allereers moet gestel word dat hierdie kerkverenigingsproses nie die eerste verenigingsproses is waarby die Ned Geref Kerk betrokke is nie ${ }^{4}$. In die laaste kwart van die negentiende eeu was dit die verenigingsproses met die Nederduitsch Hervormde Kerk wat die aandag van die Ned Geref Kerk opgeëis het. Dié proses was nie ongekwalifiseerd suksesvol nie. Tans is daar ' $n$ hernude belangstelling in die gesprek tussen die sogenaamde drie Afrikaanse susterskerke. Die veranderinge in die samelewing en in die 
politieke bestel maak dit vir hierdie drie kerke met heelwat gemeenskaplike belange 'n saak van dringende belang om nouer kontak met mekaar te soek en tot 'n helderder gesamentlike getuienis te kom as om net tevrede te wees met die byna eindelose gesprek van die Tussenkerklike Kommissie wat reeds vir 'n paar dekades voortduur. Daar is tans sprake van die vorming van 'n konvent tussen die drie Afrikaanse susterskerke om so gemeenskaplike belange beter te hanteer.

Wat die kerkverenigingsgeskiedenis van die Ned Geref Kerkfamilie betref, kan daar sonder vrees vir teëspraak gesê word dat die huidige proses waarskynlik een van die allergrootste momente en uitdagings is waarvoor hierdie kerk tot nog toe te staan gekom het. Dis slegs by 'n paar momente in die verlede dat so 'n ingrypende proses beleef is soos byvoorbeeld die vestigingsgeskiedenis teen die sewentiende eeu, die aanrakingsgeskiedenis met verskillende sendinggenootskappe sedert die begin van die agtiende eeu, die ingrypende uitbreidingsgeskiedenis sedert die laat agtiende eeu, die reoriëntasiegeskiedenis sedert die Kerkorde van De Mist (1804), die verhoudingsgekiedenis met ander kerke in Suid-Afrika in die negentiende eeu en die verwyderingsgekiedenis met sy eie jonger kerke veral in die twintigste eeu.

Die Ned Geref Kerk was vir die eerste 200 jaar van sy bestaan een kerk. Lidmate vanuit alle groeperinge (koloniste, slawe, bekeerlinge uit die inheemse volkere) het in een kerk aanbid. Veral gedurende die eerste helfte van die vorige eeu toe die sendingwerk van die Ned Geref Kerk met rasse skrede vooruitgegaan het, het die getal gelowiges wat saam aanbid het, skerp gegroei.

Tydens ' $n$ sinodesitting in 1857 is daar 'n besluit geneem wat die geskiedenis van dié kerk egter drasties sou beïnvloed. Die vraag is gevra of dit noodsaaklik is dat gelowiges uit alle groepe saam nagmaal vier en of daar ook afsonderlike byeenkomste gehou kon word? Al was die sinode oortuig dat die belydenis van die gemeenskap van die heiliges van ons vra dat ons saam aan die tafel van die Here moet sit, is besluit dat as oorgangsmaatreël, "vanweë die swakheid van sommige", daar tog verskillende nagmaalsvieringe toegelaat mag word. Wat as oorgangsmaatreël vir 'n beperkte tyd bedoel was, het egter algaande praktyk in die kerk begin word. Afsonderlike dienste vir blanke, bruin en swart lidmate het mettertyd tot die stigting van afsonderlike kerke gelei. In 1881 is die Ned Geref Sendingkerk gestig en in 1910 het die eerste sinode van die Ned Geref Kerk in Afrika tot stand gekom. Baie jare later, in 1968, het die Reformed Church in Africa (RCA) met sy Indiërlidmate (die vierde lid van die Ned Geref Kerkfamilie) sy beslag gekry. 
Vir dekades lank was die Ned Geref Kerk van mening dat die bestaan van afsonderlike kerke goed en reg was. As vrug op die sendingarbeid van die Ned Geref Kerk tussen die jare 1881 en 1985 is byvoorbeeld nie minder nie as vyftien jonger kerke sowel in die binneland as in talle Afrikalande - selfs sover as Portugal - gestig.

Gedurende die eerste vier dekades van die twintigste eeu is die denke oor kerk en sending oorheers deur die selfbewuswording van die jongkerke en hul strewe in kerkregtelike en kulturele sin. Ook in Suid-Afrika is die leiding van die Internasionale Sendingkonferensies gevolg en die klem is op selfstandigwording van die jongkerke geplaas. Inheemse kerke vir verskillende groepe sou juis die evangelieverkondiging bevorder. Die Tweede Wêreldoorlog ontnugter egter die kerk en dien as vermaning teen die impotensie van verdeeldheid. Kerkeenheid as ekumeniese ideaal word die groot strewe en met die stigting van die Wêreldraad van Kerke en die inlywing van die Internasionale Sendingraad is die Ou- en Jongkerke gelykwaardig in een organisasie saamgesnoer.

Ook in die Ned Geref Kerk word die kerkeenheidsideaal opgeneem. Inisiatief is geneem deur die Raad van Kerke en dit het in 1955 ten doel gehad om die vyf Ned Geref Kerke in Suid-Afrika te verenig. Die plan vir 'n Algemene Raad van Ned Geref Kerke het algemene byval gevind by die sogenaamde moeder- en dogterkerke en in 1960 word die Raad van Kerke van Gereformeerde Belydenis gestig, wat by sy derde sitting die Federale Raad van Ned Geref Kerke geword het. Onderling het die kerke ook vir groter eenheid gewerk. Die Algemene Sinode van die Ned Geref Kerk is in 1962 gekonstitueer en die Algemene Sinode van die Ned Geref Kerk in Afrika in 1963. Stelselmatig sou die Federale Raad ontwikkel tot die sterkste forum binne die Ned Geref Kerkfamilie om kerkeenheid te bevorder.

Die eerste kerk wat oor die kwessie van strukturele kerkeenheid besin het was die NGSK by sy sinode in 1966. Mettertyd neem die debat met ander kerke toe; tree die NGSK en NGKA toe tot die ekumeniese wêreld en kom die RCA, wat 'n besondere sterk stem tot kerkeenheid vertoon, tot stand. Tydens die sinode in 1970 maak die NGSK bekend dat hulle 'n sterk begeerte het dat 'n Algemene Sinode vir al vier die lidkerke van die Ned Geref Kerk tot stand kom - 'n besluit wat in 1974 herhaal is.

In 1976 vergader die Gereformeerde Ekumeniese Sinode (GES) in Kaapstad. Die Sowetodag gebeure en die anti-apartheidstryd tree sterk na vore in die gesprekke tussen die kerke. Voortaan neem die Ned Geref Kerk en die ander drie lede van die Ned Geref Kerkfamilie standpunt teenoor mekaar in. Na die GES neem die Ned Geref Kerk inisiatief vir 'n 
versoeningsbyeenkoms en by dié byeenkoms word 'n ad hoc-kommissie vir een kerkverband vir die Ned Geref Kerkfamilie saamgeroep. Die kommissie kom met die aanbeveling dat 'n "oorkoepelende" sinode vir die Ned Geref Kerkfamilie met jurisdiksie oor belydenis, leer, kerkorde en sake wat al die kerke gesamentlik raak, daargestel word. Die daaropvolgende Federale Raad keur die aanbeveling goed en die RCA nooi die ander lidkerke uit vir beraadslaging oor die implementering van die besluit (die NGSK was teenwoordig, die NGK stuur net 2 afgevaardigdes en die NGKA was afwesig). Eersgenoemde twee kerke neem die leiding terwyl laasgenoemde twee minder samewerking gee. Mettertyd neem die bevrydingstryd in felheid toe en in die proses bly veral die Ned Geref Kerk steeks vassteek teen eenwording.

Na 1980 kom veral twee denkstrome onder die drie jongkerke na vore om die Ned Geref Kerk se halsstarrigheid te hanteer, naamlik die voortbou op die eenwordingproses wat reeds aan die gang gesit is en 'n streng profetiese konfrontasie met gepaardgaande verbreking van amptelike bande.

Eersgenoemde benadering word voortgesit en sedert die Federale Raad se vergadering van 1984 begin die Ned Geref Kerk wegbeweeg vanaf die "Ras, Volk en Nasie" beskouing na die "Kerk en Samelewing" benadering toe. Laasgenoemde benadering word egter ook geïmplementeer, onder andere deur die Status Confessionis van die NGSK in 1982 en die opskorting van die lidmaatskap van die WBGK in Ottawa in 1982. Ongelukkig het die stryd tussen die twee strategieë die drie jongkerke in stormsee laat beland en het die RCA geskeur. Tog blyk dit asof albei benaderings bygedra het tot die Ned Geref Kerk se herbesinning en reformasie.

Die proses van kerkeenheid het vir die Ned Geref Kerk tydens die Algemene Sinode in Bloemfontein (1990) 'n duidelike vertrekpunt gekry toe die "ideaal van een kerkverband" aanvaar is, en tydens die Algemene Sinode in Pretoria (1994) het die proses verder momentum gekry toe daar besluit is om gesamentlik aan die opstel van 'n nuwe kerkorde vir een kerkverband vir die Ned Geref Kerkfamilie te begin werk. Intussen het die NG Sendingkerk en die NG Kerk in Afrika met hulle eie proses van kerkvereniging voortgegaan en het hulle vroeg in 1994 verenig onder die naam Verenigende Gereformeerde Kerk in Suider-Afrika.

Die proses van kerke wat nader aan mekaar beweeg en selfs met mekaar verenig is tans wêreldwyd sterk in fokus. Dit is 'n proses wat veral aangehelp word deur die groei van die ekumeniese gedagte, maar ook deur 'n konteks wat veel meer vra om die gesamentlike getuienis van verskil- 
lende kerke. In dié verband is dit belangrik om veral na die "Samen op Weg"-proses in Nederland en na ontwikkelinge in die Lutherse kerke in die VSA te verwys. "Samen op Weg" is 'n poging tot kerkvereniging tussen die Nederlandse Hervormde Kerk, die Gereformeerde Kerke en die Evangelies Lutherse Kerk van Nederland wat reeds in die middel sewentigerjare 'n aanvang geneem het. Wisselende suksesse is tot op hede in hierdie proses behaal.

Uit 'n onlangse onderhoud (November 1995) wat met 'n predikant van die Gereformeerde Kerke van Nederland (Gemeente Middenmeer, Wieringerpolder), ds $\mathbf{P}$ Monsma gevoer is, het ' $n$ hele aantal insigte aan die lig gekom. Daaraan sal hier kortliks aandag gegee word, alhoewel dit sterk streek(klassis) en gemeente gebonde is. Dit is opvallend hoe die situasie in Nederland streeksgewys of selfs plaaslik verskil. In sommige plekke gaan dit beter, in ander weer opvallend slegter. Dit kan aan plaaslike omstandighede, ou gevestigde en tradisionele patrone, teologiese verskille, finansies en die potensieel oorheersende rol van die groter staatskerk, naamlik die Nederlandse Hervormde Kerk toegeskryf word.

In 'n situasie soos dié van Middenmeer is dit interessant om die verskillende velde van samewerking te bekyk en te bestudeer. Dit wentel onder andere rondom jeugwerk, katkisasie, kontakaande, barmhartigheidswerk, en liturgiese en ekumeniese gespreksgeleenthede. In dié gemeenskap het dit om nouer samewerking gegaan en tans is 'n sogenaamde "federasie" sterk op die tafel. Laasgenoemde beteken egter nie samesmelting nie, omdat ook die landelike proses in Nederland nog nie sover is nie.

Verder is dit duidelik dat hoe verder die proses ontwikkel het, hoe meer het die kerke bewus geword van hulle vrese, frustrasies en verskille. Daar is dikwels in kerkvergaderinge gepraat van "ons" en "hulle", van die verskille in kerkwees en gemeentewees, en van die verskille in beklemtoninge: "We hebben allebei een klimaat geschapen, waarin we ons gelukkig voelden. We koesterden ons beiden in de warmte van het eigen nest". Dit is opvallend hoe sterk verskillende elemente in die betrokke kerke voel oor die noodsaaklikheid van kerkvereniging en die belangrikheid van 'n gesamentlike getuienis: "Het kan eenvoudigweg niet meer stoppen".

Die proses in Nederland verloop dus nie sonder stamp of stoot nie. Tans is dit hoofsaaklik die Nederlandse Hervormde Kerk wat die rem in die proses aangeslaan het. Hulle ondervind probleme met die voorgestelde nuwe kerkorde en bepaalde lidmate binne die Gereformeerde Bond groepering in die Hervormde Kerk het ook steeds reserwes oor kerkvereniging. Gedurende November 1995 het hulle sinode 'n gesprek gevoer oor die tema "Geloven we in dezelfde God?". 
In nog 'n onderhoud met 'n predikant van die Gereformeerde Kerke van Nederland, drs M van der Sijs (Januarie 1996) stel hy dat 1996 'n baie kritieke jaar vir die "Samen op Weg"-proses sal wees. Alhoewel hy nie as 'n amptelike woordvoerder opgetree het nie, is hy nie oningelig oor die ontwikkelinge nie. Hy het die sterk verskille van gemeente tot gemeente en van streek tot streek beklemtoon. Hy was minder optimisties oor die proses en het gestel dat indien sake nou vasval, kan dit selfs vir so lank as twintig jaar vertraag word.

Ook in die geval van die Lutherse samesmelting in die VSA het hierdie proses met heelwat groeipyne gepaard gegaan. Ten spyte van gebede, ' $n$ gees van welwillendheid en entoesiasme, is die vroeë bestaan van die nuwe kerk deur twee tendense gekenmerk: op plaaslike vlak en in die daaglikse lewe van gemeentes het sake redelik vlot verloop. In die landswye organisasie van die kerk het egter groeipyne voorgekom ten spyte van aanvanklike positiewe ontwikkelinge oor 'n breë front. Insiggewend is die volgende kommentaar oor die vorming van hierdie nuwe kerkformasie tussen die "Lutheran Church in America", die "American Lutheran Church" en die "Association of Evangelical Lutheran Churches". Die nuwe kerk staan as die "Evangelical Lutheran Church in America" bekend. 'n Biskop van die voormalige "Lutheran Church in America” J R Crumley stel dit so: “...the new church was not created to correct errors in the existing churches, nor to address a new context in which the churches found themselves. Rather, 'the motivation for forming the new church was a sense of the unity of the church', he said. It would not have new theology, but new organization. Some aspects of this newness are simple and straightforward: new synod boundaries...; new synod leadership...; new headquarters city, building, and procedures...; the loss of memory. In the churchwide organization, no officers had held similar positions in the predecessor bodies, and only five of 21 executive directors had done so...; lack of emphasis on retaining former staff...; some systems and procedures in the predecessor churches that had proven effective were laid aside, with lesser experienced people trying to replace them with something new...; new funding patterns...; new patterns of seminary linkages, funding and governance...; divided women's emphases...; no social statements...; social statements of the predecessor churches were brought forward as 'historical documents', not as positions of the new church...; very little emphasis was placed on cost or on how the structure was a political compilation of its parts...; of all the 'new' features, none had broader impact than quotas" 5 . Twee jaar na die samesmelting sê Crumley: "The quota system causes the church to fall into 
the trap of overlooking the charism (the gifts), or else to say that the gift of gender or race is a greater charism than others of experience or training. I believe that to be a misunderstanding of the way in which God preserves the church by giving different gifts to people"6. Dit blyk dat veral vyf groot sake die hele verenigingsgesprek oorheers het, naamlik die grootte van pensioenbydraes, die ekumene, bediening, ekklesiologie en die kwessie van kwotas.

Opvallend is dit ten slotte dat die een groot verskil in die kerkverenigingsproses van die Ned Geref Kerkfamilie teenoor haas alle ander verenigingsprosesse elders ter wêreld daarin lê dat die Ned Geref Kerkfamilie sedert 1857 op 'n rassebasis van mekaar geskei was en dat daar tans geen ander teologiese en prinsipiële keuse is as dat die saak aangespreek moet word nie. Daar is dus nie wesenlike kerklike en teologiese verskille soos dit dikwels by ander verenigingsprosesse die geval is nie.

\section{3 'N PRINSIPIEEL-KERKREGTELIKE PERSPEKTIEF}

Ek wil u vandag saamneem op 'n kerkregtelike tog wat na my mening van baie groot belang is. Ek hoop nie dat $u$ reaksie sou wees soos wat 'n Nederlandse vakgenoot in die kerkreg, Leo Koffeman van die Theologische Universiteit van Kampen onlangs in Nederland ervaar het nie. Teenoor hom is gevra: “'Vind je dat dan leuk?' Kerkrecht roept in eerste instantie kennelijk niet snel positieve reacties op. Het riekt naar formalisme, stoffigheid en misschien zelfs heerszucht" 7 . U sal egter gou bemerk dat my invalshoek op die kerkreg een is wat ek van harte glo die regte een is, naamlik dat dit in die eerste en laaste plek moet gaan oor die "regering van Christus in sy kerk"8.

Die Bybel laat geen twyfel oor die waarmaking van die eenheid van die kerk nie. Die Bybel praat duidelik en reguit oor die kerk as die liggaam van Christus in 'n enkelvoudskarakter. Die eenheid van die kerk is 'n gegewe eenheid, 'n gawe van Christus aan sy kerk. Ook Paulus spreek hom sterk uit teen groepvorming in die kerk. Eenheid bring op sy beurt weer verskeidenheid, maar vloei voort uit die eenheid en staan nie daarteenoor nie.

In kerkvereniging sal ons die plek en rol van kerkreg in regte perspektief moet plaas. Eerstens sal ons moet weet dat kerkwees gekoppel word aan verantwoorde kerkregering. Die ware kerk is immers daar te vinde waar die Woord verkondig word, die sakramente bedien en die regering van die kerk deur opsig en tug beoefen word. Tweedens gaan dit 
in kerkregering om die regering van Christus in sy kerk, dit wil sê 'n geestelike regeringswyse deur Gees, Woord, belydenis en kerkorde. Ons sal soos elders óók in die kerkverenigingsproses daarteen moet waak dat kerkreg verlaag word tot 'n rigiede juridiese aangeleentheid waar volgens die letter van die "kerkwet" gedink en gedoen word. Die kerkreg het in hierdie proses naas ' $n$ regulerende ook 'n fasiliterende taak. Die kerkorde het nie 'n eie gesag nie; dit mag nie as 'n bundel statute toegepas word nie en dit bly altyd 'n rigtingpyler na die Woord van God. Kerkreg het ook alles met ekumene te make.

In kerkvereniging sal 'n paar belangrike kerkregtelike riglyne in ag geneem moet word. Voorop staan die koninkryk van God as konteks vir kerk en orde. Vervolgens moet Jesus Christus as enigste Hoof en Here van die kerk gesien word wat deur Woord, Gees en dienste regeer. Derdens moet die kerk as 'n unieke gestalte in die koninkryk raakgesien word. Hierdie unieke gemeenskap word deur die verkondiging tot eenheid versamel. 'n Verantwoorde kerkbegrip het positiewe implikasies vir kerkreg en kerkregering. Vierdens het kerke nie net die indikatief nie, maar ook die imperatief tot een kerkverband, want deur hulle belydenis van Christus as Here is hulle na gelang van verskillende faktore vaster of losser aan mekaar verbind. Kerkverband is die uitlewing en belewing van die familiekarakter van die kerk. Ten slotte moet liefde en begrip vir vrese en frustrasies die kanaal en die opbou van die gemeente die doel wees tot kerkvereniging?.

Soos deur Crafford aangedui, word vier uitgangspunte as deurslaggewend vir die proses van kerkvereniging beskou ${ }^{10}$. Eerstens moet die grootste mate van sigbare en strukturele eenheid nagestreef word. Die wesenlike eenheid tussen kerke word bepaal deur 'n gemeenskaplike belydenis en kerkregeringstelsel asook deur hulle historiese verbondenheid aan mekaar. Tweedens moet genoeg ruimte gelaat word vir die verskeidenheid van tale, kulture, spiritualiteit en bedieningsbehoeftes wat in die kerke bestaan. Hierdie realiteite in 'n multi-kulturele samelewing kan nie geïgnoreer word nie. Derdens moet die gereformeerde belydenisskrifte gehandhaaf bly en die gereformeerde kerkregeringsvorm moet as basis dien. Kerkeenheid word volgens Crafford gekonstitueer deur 'n gemeenskaplike verstaan van die waarheid en deur 'n gemeenskaplikheid in kerkregerings- en liturgiese vorme. Indien dit nie sou bestaan nie, lei dit tot 'n pluriformiteit wat ander tipe ekumeniese bande vereis en nie noodwendig strukturele eenwording nie. Vierdens moet die kerkverenigingsproses so verloop dat die meerderheid van die lidmate in die betrokke kerke hulle daarmee kan vereenselwig. Indien kerkvereniging sou lei tot 
verdere versplintering van die kerk, word die gees en bedoeling van die proses juis verongeluk.

Nog voor die belangwekkende besluite van die Algemene Sinode van die Ned Geref Kerk van 1994 het die dagbesture van die Algemene Sinodale Kommissies van die verskillende gesprekvoerende kerke die volgende verklaring uitgereik na samesprekings wat op 11 Augustus 1994 plaasgevind het. Ook dit het 'n bepaalde gees van hoop geadem wat die pad verder vir kerkeenheid help berei het. Positief in hierdie verklaring is die identifisering van velde van ooreenstemming eerder as om voortdurend op die verskille te hamer. Uiteraard mag die verskille nooit geïgnoreer word nie. Die dagbesture van die Algemene Sinodale Kommissies van die Verenigende Gereformeerde Kerk in Suider Afrika (VGKSA) en die Ned Geref Kerk het herbevestig dat gehoorsaam aan die Skrif en in ooreenstemming met die onderskeie sinodale besluite van die betrokke kerke, dit steeds hulle erns is om sigbare uitdrukking te gee aan die eenheid van die VGKSA en die Ned Geref Kerk, en dat hulle 'n geskikte struktuur daarvoor wil vind. Hulle bevestig weer hulle toewyding daaraan om hierdie ideaal so gou as moontlik 'n werklikheid te maak. Oor die volgende sake het hulle saamgestem:

"Dat as belydenisgrondslag die VGKSA en die Ned Geref Kerk die drie Formuliere van Eenheid in gemeen het. Vir die VGKSA is die Belydenis van Belhar 'n vierde belydenisstuk. Die Ned Geref Kerk word versoek om te oorweeg of hy dit ook in beginsel as belydenisskrif van 'n eenheidskerk sou kon aanvaar.

Dat, op grond van Skrifbeginsels, 'n kerkorde vir die eenheidskerk opgestel sal word met die kerkordes van die huidige kerke as uitgangspunt.

Dat 'n ad hoc-kommissie van die dagbesture aandag gee aan die voorlegging van die VGKSA oor stappe onderweg na eenheid, en die moontlikheid oorweeg om aan die hand daarvan en in die lig van kommentaar van die VGKSA op die riglyne vir 'n model vir een kerkverband van die Ned Geref Kerk, op 'n geskikte wyse 'n aanbeveling aan die Algemene Sinode van die Ned Geref Kerk te maak oor die kerkordelike weg om te volg tot 'n eenheidskerk".

Die dagbesture het hulle voorneme herbevestig om die Reformed Church in Africa (RCA) by die proses van kerkvereniging te betrek, en bogenoemde besluite word aan die RCA voorgelê. 
Gedurende Maart 1995 is 'n belangrike stap voorwaarts geneem met die oog op die skryf van 'n konsepkerkorde vir een kerkverband vir die Ned Geref Kerk, die Verenigende Gereformeerde Kerk en die Reformed Church in Africa toe die sogenaamde Gesamentlike Kommissie van dié drie kerke vir die eerste keer vergader en planne agtermekaar gekry het oor hoe te werk gegaan sal word om 'n konsepkerkorde te skryf ${ }^{11}$. Hoe die nuwe strukture en die een kerkverband uiteindelik daar sal uitsien, sal algaande uitgewerk word.

'n Verskeidenheid van eenheidsmodelle tussen kerke is moontlik: Die Rooms Katolieke model impliseer 'n hiërargiese eenheid, die Ortodokse model 'n konsiliêre eenheid en die Wêreldraad van Kerke model 'n organiese eenheid. Laasgenoemde impliseer eenheid eers op plaaslike vlak voordat dit op breëre vlak plaasvind. Vervolgens is daar die konsultatiewe model waarvolgens rade ontstaan waarop verskillende kerke verteen-woordig is en as "eenheid" word bepaalde gesamentlik projekte aangepak. Die modaliteiteenheidsmodel laat ruimte vir taal-, kultuur-, leeren spiritualiteitsverskille binne een verbonde gemeenskap. Volgens die geestelike eenheidsmodel is die ware kerk onsigbaar, want net God weet wie ware gelowiges is. Die eenheid hoef dus slegs geestelik nagestreef te word. Die eskatologiese model impliseer dat die eenheid eers bereikbaar is op die nuwe aarde na die wederkoms van Christus ${ }^{12}$.

Die vraag ontstaan watter eenheidsmodel deur die Ned Geref Kerkfamilie nagestreef moet word. Die maksimum eenheidsmodel is die van organiese eenheid, maar dit is moeilik te realiseer as gevolg van veral taal en kultuursverskille. Die minimum eenheidsmodel bepaal slegs die erkenning van mekaar se lidmaatskap en ampte asook toegang tot mekaar se sakramente. Êrens sal vir 'n model tussen hierdie twee uiterstes gekies moet word.

Die model wat tans deur die ASK van die Ned Geref Kerk as 'n gespreksdokument aangebied is, kom neer op 'n oorkoepelende sinode tussen die drie gesprekvoerende kerke. Binne hierdie struktuur bestaan gemeentes, ringe en sinodes voort solank hulle dit verkies. Deur samewerkingstrukture moet in die verloop van tyd 'n groeiproses op dreef kom ten einde groter sigbare eenheid tot stand te bring. Dit mag egter gebeur dat hierdie groeiproses so stadig sal verloop dat die eindpunt moeilik bereik sal word.

Die model van die VGKSA wat sterk oorweeg moet word, kom daarop neer dat die Algemene Sinode, streeksinodes en ringe met mekaar verenig op grond van 'n gemeenskaplike kerkorde. Gemeentes word toegelaat om te funksioneer soos hulle tans bestaan, alhoewel die ideaal bly 
bestaan dat gemeentes sal verenig waar dit enigsins moontlik is. Dit laat dus ruimte vir 'n groeiproses na mekaar. Om vir die beginsel van verskeidenheid ook tot op gemeentevlak ruimte te skep, kan wyksgemeentes met eie kerkrade georganiseer word om vir verskillende taal- en kultuurgroepe asook vir spiritualiteitsverskille voorsiening te maak.

Die kerkregtelike proses rondom kerkvereniging in die Ned Geref Kerkfamilie sal soos volg verloop: By die eerste vergadering van die Gesamentlike Kommissie is besluit om 'n sewetal subkommissies daar te stel wat verskillende velde dek en aan sake wat by die skryf van die nuwe kerkorde op die spel is, aandag te gee. Alle kommentaar wat van lidmate, kerkrade, ringe en sinodes ontvang word, sal deur die Algemene Sinodale Kommissie (ASK) verwerk en aan sy verteenwoordigers in die Gesamentlike Kommissie deurgegee word wat dit weer na die verskillende subkommissies sal kanaliseer. So gou as wat die Gesamentlike Kommissie 'n konsepkerkorde gereed het, sal die Algemene Sinodale Kommissie (ASK) dit aan die verskillende kerklike vergaderings van die Ned Geref Kerk voorlê. Dit sal ook vir die tweede konsepkerkorde geld, waarna die Algemene Sinode dit waarskynlik finaal sal goedkeur. Tot in die finale stadium sal kerkrade en lidmate met behulp van die voorgeskrewe prosedure die pad van kerkvereniging vollediglik kan saamloop.

Intussen gaan die werk van die subkommissie vir 'n nuwe konsepkerkorde onverpoosd voort en 'n aantal oriënterende gesprekke is reeds gevoer. Die afgevaardigdes van al drie die gesprekvoerende kerke by hierdie Kommissie is dit egter met mekaar eens dat alvorens die vorm van kerkverband nie bepaal is nie (dit wil sê 'n losser samewerkingsverband of 'n kerkvereniging wat uiteindelik tot op gemeentelike vlak sal deurwerk), daar nie werklik finaliteit aan 'n kerkorde gegee kan word nie. Om op hierdie stadium dus op kerkordelike implikasies in te gaan is nog nie moontlik nie.

\section{4 'N PRAKTIES-KERKREGTELIKE PERSPEKTIEF}

Die vraag ontstaan wat die kerk in die breë en veral plaaslike gemeentes op hierdie stadium aan kerkvereniging kan doen. In laasge-noemde verband bestaan daar aldus vir die Algemene Sinodale Kommissie verskeie moontlikhede, naamlik voorbidding vir die eenheidsproses, die inlig van lidmate oor die noodsaaklikheid van eenheid, oor die beginsels wat op die spel is en die proses wat gevolg behoort te word, en oor maniere waarop die proses van kerkeenheid plaaslik bevorder kan word.

Een van die belangrikste samewerkingsaksies op gemeentelike vlak naas andere op ringsvlak, is dat twee gemeentes in die Wes-Kaap besig is 
om geleidelik na mekaar te groei. In die Maitland-omgewing het die belange van die gemeentes van die Ned Geref Kerk en die voormalige Ned Geref Sendingkerk (tans die gemeente van die Verenigende Gereformeerde Kerk van Suidelike Afrika) so verstrengel geraak dat dit eintlik voor die hand liggend was dat hulle nouer bande sou smee en tot groter samewerking sou kom. Dit blyk dat hierdie twee gemeentes reeds indringende stappe geneem het om tot eenheid te kom. Dit blyk egter ook dat hierdie gemeentes te doen kry met 'n hele aantal pynlike realiteite soos die geskiedenis van hierdie gemeentes, die onrypheid van lidmate vir kerkvereniging, die onsekerhede oor die toekoms en 'n ontoereikende begeleiding ten opsigte van die kerkregtelike implikasies van kerkvereniging. Aangesien hierdie gemeentes waarskynlik van die enigstes in Suid-Afrika is wat reeds besig is om ook op gemeentelike vlak tot nouer samewerking en na kerkvereniging te beweeg, kan die kerk in die breë heelwat uit hulle suksesse en mislukkings tot hiertoe leer.

As daar gevra sou word na die redes waarom hierdie twee gemeentes heelwat pyne rondom kerkvereniging beleef kan dit waarskynlik aan die volgende faktore gewyt word: Skynbaar is die spesifieke doelwitte van die kerkverenigingsproses aanvanklik nie duidelik genoeg uitgespel nie. Oor die beslissingsmag van die betrokke vergaderings was daar eweneens nie genoeg duidelikheid nie. In die verband moes die werkswyse aanvanklik duideliker uitgespel word.

Ook die terminologie wat in die proses en in verskillende vergaderings gebruik word, is aanvanklik nie genoeg omskryf en uitgeklaar nie. Hiernaas is dit ook belangrik dat 'n duidelike etos vir die eenwordingsproses ontwikkel moet word. Eensydige besluite en aksies mag nie ter sprake wees nie. Verder moet kommunikasie voorop staan. Vrese en frustrasies moet hanteer word en dit kan wentel rondom verskillende agendas, 'n identiteitskrisis, rassisme, finansies of spiritualiteits-verskille.

'n Aantal lesse vir die kerkreg behoort uit die pynlike ervaring in die Maitland konteks en ook elders geleer te word. Oor die vertrekpunte en doel van kerkvereniging moet daar geen twyfel bestaan nie. Oor begrippe soos eenwording of samewerking en hulle betekenis moet vroegtyd duidelikheid verkry word. Hoofsake en bysake moet duidelik van mekaar onderskei word en knelpunte en slaggate moet geïdentifiseer word. Wanneer 'n proses vasdraai hoef dit nie noodwendig negatief te wees nie. In so 'n situasie is dit egter belangrik om dit as deel van 'n ernstige worsteling te sien en om daarteen te waak om vuil wasgoed in die openbaar te was en ' $n$ beskuldigende houding aan te neem. Volgens 'n onderhoud met ds J Botes van die Ring van Kaapstad (26/12/1995) bly dit belangrik 
om die skriftuurlike uitdaging voorop te stel. Die geskiedenis en konteks van 'n situasie behoort verreken te word. Die fokus in onderhandelinge moet sterker op gemeenskaplikhede as op verskille gerig word en daar moet nie gepoog word om punte teenoor die ander party aan te teken nie. In nederigheid en ootmoed voor mekaar en voor God en deur volhardende gebed moet die weg tot beter begrip en groter samewerking gesoek word.

By die pasafgelope Sinode van die Ned Geref Kerk in Suid-Afrika Wes- en Suid-Kaap is ' $n$ belangrike kerkregtelike aksie onderweg na kerkvereniging geneem, toe 'n nuwe Reglement 12A geformuleer en tot die bestaande Reglement 12 toegevoeg is. Hierdie reglement handel oor die kombinasie van die werksaamhede van gemeentes, ringe en sinodes/kommissies van sinodes uit verskillende kerkverbande en bied waardevolle riglyne vir prakties konkrete aksie deur die kerk in die breë. Dit is 'n reglement wat met goeie vrug deur ander streeksinodes as model gebruik en aangepas kan word vir plaaslike behoeftes.

Crafford ${ }^{13}$ onderskei 'n aantal prakties-konkrete knelpunte in die kerkverenigingsproses, naamlik die Belhar-belydenis, teologiese verskille, verskille in spiritualiteit, verskille in bedieningsbehoeftes wat saamhang met verskille in taal en kultuur, finansiële probleme rondom eiendomme, inkomsteverskille van predikante en lidmate, tradisionele rassegevoelens en wantroue, teologiese opleiding, ekumeniese betrekkinge en die kerknaam. 'n Enkele opmerking is egter hier ter sake. Wat die Belharbelydenis betref moet dit duidelik gestel word dat die teologiese identiteit van die Ned Geref Kerkfamilie deur die Formuliere van Eenheid bepaal word en dat dit die basis vorm vir sy teologie. Aangesien die Belharbelydenis nie in stryd met hierdie belydenisskrifte is nie, kan dit as bykomende belydenisskrif erken word, maar dan met die veronderstelling dat dit 'n geloofsinterpretasie binne 'n bepaalde konteks verteenwoordig.

Met betrekking tot belydenisskrifte en belydenisvorming handhaaf die VGKSA 'n oop benadering wat in die proses van onderhandeling ruimte skep vir gesprek en die uitwisseling van gedagtes en kompromieë. Die VGKSA het aanvaar “dat sy taak van belydenisvorming nie afgehandel is nie. In die toekoms mag veranderde omstandighede en 'n beter verstaan van die Woord van God lei tot die aanvaarding van verdere belydenisskrifte of die wysiging van bestaande belydenisskrifte".

Met betrekking tot teologiese opleiding moet gestel word dat opleiding die eenheid moet dien en nie toelaat dat dit uiteenloop nie. Verskillende kultuurgroepe behoort op die personeel van teologiese fakulteite verteenwoordiging te kry en so kan vir verskillende aksente voorsiening gemaak word. Voortgesette kwaliteit opleiding in die gerefor- 
meerde teologie moet voorop gestel word. Wat spiritualiteitsverskille betref, is dit noodsaaklik dat daar ruimte hiervoor geskep moet word. 'n Kerkraad kan wyksgemeentes skep wat voorsiening maak vir verskille in spiritualiteit, taal en kultuur.

Ook wat die naam van die toekomstige verenigde Ned Geref Kerk betref, lê daar 'n hele aantal uitdagings voor wat ook kerkregtelike implikasies het. Moontlike name vir die nuwe verenigde kerk is byvoorbeeld die volgende: Die Nederduitse Gereformeerde Kerk in Suidelike Afrika, die Gereformeerde Kerk in Suidelike Afrika of die Verenigde Gereformeerde Kerk in Suidelike Afrika. Daar lê egter heelwat emosie in die ou en nuwe kerkname en ook hierdie saak sal met groot omsigtigheid hanteer moet word.

In 'n bydrae tot die gesprek oor kerkeenheid en kerkvereniging wat deur die Werkgemeenskap vir Kerkreformasie en die Voortsettingskomitee uitgegee is, word die vraag gevra of dit gaan oor eenvormige verskeurdheid of veelvormige eenheid. Volgens dié dokument hou die praktiese implikasies van kerkvereniging die kiem van eenvormige verskeurdheid in. Dit wentel veral om die wysiging van die kerk se belydenisskrifte, bindende besluite oor leerstellige en belydenissake, ander liturgiese formuliere, taalmedium en bedieningspatrone wat verander, probleme ten opsigte van pastorale arbeid, verdeeldheid en skeuring binne die eie kerk, en die verandering van kerknaam en gemeentegrense.

Intussen is daar ook onopgeloste spanning in die Oranje-Vrystaat en die Noord-Kaapse sinodale streke waar die Ned Geref Kerk in Afrika nie by die VGKSA ingeskakel het nie. Die Ned Geref Kerk in Afrika in dié gebied wil eerder op hierdie stadium nouer skakeling met die Ned Geref Kerk handhaaf. Dit veroorsaak onsekerheid en frustrasie by al die partye.

Gedurende Oktober 1995 het 'n besluit van die Lynnwoodgemeente in die sinodale streek van Noord-Transvaal 'n wending in die gesprek rondom kerkvereniging van die Ned Geref Kerkfamilie veroorsaak met die versoek tot opskorting van onderhandelinge ten opsigte van kerkvereniging, hangende ' $n$ finale beslissing en verklarende bevel van die Hooggeregshof oor 'n aantal vrae. Hierdie vrae handel oor kerkregtelike kwessies en oor die geldigheid van besluite van verskillende kerkvergaderings oor kerkvereniging, asook die vlak van instemming wat van lidmate in die verband verkry moet word. Hierdie saak is gedurende November 1995 by die moderamen van die Ned Geref Kerk van NoordTransvaal in gesprek geneem wat dit op sy beurt weer na die Algemene Sinodale Kommissie verwys het wat op 1 Desember 1995 daaroor beraadslaag en daarvan kennis geneem het. Daar is korrek besluit om 
regsadvies daaroor in te win en gedurende Januarie 1996 het hierdie proses verdere voortgang geniet. Daar is ook besluit dat die gesprek intussen kan voortgaan terwyl die regsadvies afgewag word.

\section{SLOTOPMERKINGS}

Vervolgens moet 'n aantal slotopmerkings gemaak word wat ten doel het om die konkrete kerkregtelike worsteling oor kerkvereniging ten dienste te wees. Hierdie opmerkings word gerig nie alleen aan die adres van meerdere kerkvergaderings nie, maar ook aan predikante, ampsdraers en lidmate wat in plaaslike gemeenteverband by kerkvereniging betrokke is.

Eerstens moet gestel word dat kerkvereniging in die Ned Geref Kerkfamilie 'n prinsipieel verdedigbare uitdaging en imperatief is. Tweedens sal hierdie proses met nugterheid en met die verantwoordelikheid, sensitiwiteit en begrip vir al die partye daarby betrokke asook hulle vrese en frustrasies aangepak moet word. Kerkvereniging kan, soos die kerkgeskiedenis ons leer, dikwels tot afsplintering lei. Derdens is dit noodsaaklik dat die verskillende kommissies wat betrokke is by die beslaggewing van kerkeenheid met oortuiging en met omsigtigheid te werk sal moet gaan om die eenheid so te beplan en te bou dat praktiese, kerkregtelike en regsprobleme nie hierdie belangrike saak sal kelder nie. Vierdens sal daar 'n goeie wil en ook 'n bereidwilligheid moet wees by die verskillende partye om in afhanklikheid van God en in 'n gees van samewerking, versoening en ernstige studie van die Skrif met die proses voort te gaan. Vyfdens is dit belangrik om nugter en eerlik na die verskeidenheid van knelpunte op pad na kerkeenheid te kyk. Dit is ook belangrik om na gemeenskaplikhede te kyk wat kerke in 'n kerkverenigingsproses saambind.

Die konteks waarin ons lewe stel besondere eise aan die kerk in die algemeen in die nuwe Suid-Afrika en aan die Ned Geref Kerkfamilie in die besonder. Alhoewel daar baie pyne op weg na 'n meer verenigde Ned Geref Kerkfamilie vir ons voorlê, is die uitdaginge en die geleenthede vir so 'n verenigde kerk geweldig groot. Te midde van baie probleme op die pad van kerkvereniging sal ons ons prioriteite reg moet hou en dit suiwer instel. Ons sal by hernuwing moet bely dat ons deel is van die een heilige algemene christelike kerk wat deur die drie-enige God, Vader, Seun en Heilige Gees deur sy Gees en Woord versamel is om die een liggaam van Christus op aarde te vorm; dat die eenheid van hierdie kerk nie net gawe van God is nie, maar ook op grond van die uitdruklike gebed van die Here in Johannes 17, aktief gesoek en sigbaar gemaak moet word sodat die wêreld kan glo dat God sy Seun gestuur het. 
Dat die wagwoorde op die weg van kerkvereniging in die Ned Geref Kerkfamilie tweërlei moet wees, is duidelik. Aan die een kant moet ons leuse wees en bly: "Saam op soek na 'n nuwe weg!". Aan die ander kant moet die wagwoord wees een van langsame haas. Nicol ${ }^{14}$ bepleit dit soos volg: "Ek kan nie sien hoe dit die wil van die Gees kan wees dat ons 'n klomp mense afskud om gouer te kan verenig nie. Daarom moet ons op die twee bene van sterk oortuiging en geduld loop. Sterk oortuiging dat ons behoort te verenig, en geduld om almal daarin saam te neem".

Mag ons hoop dat in die jaar wat voorlê die mikpunte wat ons vir en met mekaar in hierdie kerkverenigingsproses stel, bereik sal word; dat die oorwinning waarvoor ons hoop werklikheid sal word; dat dit eerder 'n maak as 'n breekjaar sal wees; dat die tafel gedek sal word vir vergesigte van hoop, bevryding, skoonheid, en vrugbaarheid en dat ons inderdaad "shall hang together" in plaas daarvan om te "hang separately". Ek glo van harte dat dit in vele opsigte 'n goue jaar kan word. In daardie wete en geloof kan 'n mens byna nie op 'n beter wyse afsluit as om die woorde van een van die "Samen op Weg"-liedere vanuit Middenmeer in Nederland te laat weerklink nie:

"Samen in de naam van Jezus, heffen wij een loflied aan, want de Geest spreekt alle talen, en doet ons elkaar verstaan, Samen bidden, samen zoeken, naar het plan van onze Heer samen zingen en getuigen, samen leven tot Zijn eer" ${ }^{15}$.

\section{NOTAS:}

1 Referaat gelewer tydens die predikantekonferensie van die Fakulteit Teologie (Afd B) Universiteit van Pretoria, Januarie 1996.

2 R Botman, "Kerkeenheid kan nie sonder belydenis van Belhar nie", Die Kerkbode 156/22 (15/12/1995), 3.

$3 \quad$ Kerk en Samelewing, 1990, paragraaf 73.

4 D Crafford en G Gous (red), Een liggaam, baie lede, Pretoria 1993, 275-403.

5 E R Trexler, Anatomy of a merger, Augsburg (Minneapolis) 1991, 258-259.

6 Trexler, $a w, 261$. 
7 L Koffeman, “Het voordeel van kerkrecht is het nadeel”, Communique 10/3, (1994), 32.

8 Vergelyk W D Jonker, Om die regering van Christus in sy kerk, Pretoria, 1965.

9 P Coertzen, Gepas en ordelik, Pretoria 1991, 75-116. Vergelyk ook P Strauss (red), Byderwets en gereformeerd, Bloemfontein 1991, 187-222.

10 D Crafford, "Kerkvereniging binne die Ned Geref Kerkfamilie: Uitdagings en probleme", Skrif en Kerk 17/2 (1996).

11 Die Kerkbode 155/9 (17/3/1995), 1.

12 A König, “Modelle van kerkeenheid", in: P G J Meiring en H I Lederle (reds), Die eenheid van die kerk, Pretoria 1979, 89-101.

13 Crafford, $a$ w.

14 W Nicol, “God wat kerke-familie verenig”, Beeld, 22/8/1995.

15 Lied 72 uit die bundel Samen Zingen, Middenmeer oorgeneem uit Zangbundel ten dienste van huisgezin en samenkomsten ${ }^{28} 1991$, hersien deur J Q Zwart. 